\title{
APPROPRIATION AND POLITICAL EXPRESSION IN URBAN PUBLIC SPACES
}

\section{APROPRIAÇÃO E EXPRESSÃO POLÍTICA NOS ESPAÇOS PÚBLICOS URBANOS}

\author{
Sergio Luis Abrahão \\ FIAM-FAAM Centro Universitário, Programa de Pós-Graduação em Projeto, \\ Produção e Gestão do Espaço Urbano, São Paulo, São Paulo, Brasil
}

\begin{abstract}
A B S T R A C T : There are many, diverse issues that determine the relationship between citizens and their public urban spaces and, consequently, the significance that these spaces acquire for society as a whole. In totalitarian regimes however, the use of streets and parks as places of protest and resistance against sequestered freedom is not permitted. However, in democratic regimes, the reflections and discourse of architects, urbanists, researchers and policy makers regarding the manner in which public urban space is (or should be) appropriated by the population, has revealed a systematic reinterpretation of these spaces. Indeed, ever since the last decades of the past century, it has become recurrent to associate these physical spaces with the space of political realization. The intention of the present article is to bring the meaning of this association into debate, above all due to the insurgencies from certain segments of our population, which have taken place over recent years, manifestly in the streets, parks and avenues of our cities.
\end{abstract}

K E Y W O R D S : public spaces; urban spaces; political expressions; insurgencies; appropriations.

R E S U M O : São muitas e diversas as questóes que determinam a relação dos cidadãos com seus espaços públicos urbanos e, por conseguinte, o significado que esses espaços assumem para o conjunto da sociedade. Em regimes totalitários, por exemplo, não se permite o uso das ruas e praças como lugares de manifestaçóes e resistência à liberdade confiscada. No entanto, nos regimes democráticos, as reflexóes e discursos de arquitetos, urbanistas, pesquisadores e gestores públicos, em torno do modo como o espaço público urbano é (ou deveria ser) apropriado pela população, tem evidenciado uma sistemática ressignificação desses espaços. Com efeito, desde as últimas décadas do século passado tornou-se recorrente associar esses espaços físicos ao espaço da realização politica. Este trabalho pretende trazer ao debate o sentido desta associação entre cidadáos e espaços públicos urbanos, sobretudo frente às insurgências de segmentos de nossa população, como vem ocorrendo nos últimos anos, manifestadamente nas ruas, praças e avenidas de nossas cidades.

P A L A V R A S - C H A V E : espaço público; espaço urbano; expressão politica; insurgências; apropriaçôes.

DOI: https://doi.org/10.22296/2317-1529.2016v18n2p291 


\section{INTRODUCTION}

Since the last decades of the previous century, there has been a recurrent theme in the discourse of administrators, architects and planners associating the physical space of our streets, squares and avenues with a space for political achievements, in which a particular form of social bond and relationship with power is developed. The strength of this association has resulted in the indistinct use of the term "public space", not only as a manner of designating our streets, squares and avenues, as immanent spaces of urban morphology or as protagonists in the processes of urbanist interventions, but also to identify the space where the public sphere and that of public life are manifested, as defined by Habermas (1984), Arendt (1993) and Richard Sennett (1988), among others.

Over recent decades, there have been numerous publications, official documents and seminars that have analyzed the appropriation and use of our streets, squares and parks, from the viewpoint of democracy, citizenship and urbanity, in short - as spaces for political achievement. With the exception of authors such as Carlos Nelson Ferreira dos Santos (1981; 1984), Rosalyn Deutsche (1998), Sharon Zukin (1996) and David Harvey $(2006 ; 2014)$ among others, discourses and reflections that involve political achievement in urban public spaces have conveyed a concept of political public space, which presupposes, drawing on Delgado (2011, p. 20, author's translation): "a realm of peaceful and harmonious coexistence by all that is heterogeneous in our society, which demonstrates that what we are allowed to do in society is to place ourselves in accordance with a set of programmatic postulates within which the differences are seen to be overcome."

Delgado attributes this understanding of political public space as one of the conceptual ingredients of what he called a citizenist ideology. Towards this direction, Rosalyn Deutsch (1998) attests that in her view, this ideology understands democracy not as a form of government, but as a way of life and as an ethical association. Thus, the overlap of political space in the materiality of our streets, squares and avenues in which the citizenist illusion is dramatized, in her view, functions as a "mechanism whereby the contradictions that support the ruling class remain unseen, while at the same time they obtain the approval of the dominated class for the worth of the political system to convince those who are dominated of its neutrality" (DELGADO, 2011, p. 24, author's translation).

The present paper aims to bring to debate the role of our streets, squares and avenues, as spaces of political expression within the urban context, seeking to demonstrate that such a political expression comes into being when there is evidence of contradictions in the process related to dominating those spaces by the ruling classes, and calls into question the idea of urbanity, as a system of good civic practices, repeatedly conveyed through planning and policy management submitted to the interests of the ruling minority. To guide the occasioned debate we will observe the places and reasons for which over recent years, large demonstrations have taken place in our cities, and seek to examine them in the light of the political significance that has been attributed to urban public spaces. 


\section{POLITICAL EXPRESSIONS IN THE URBAN PUBLIC SPACES}

Over recent years, the number of demonstrations has intensified all over the world, especially in Brazil, with groups of people claiming their constitutional rights to housing, free high quality public transport, participation in state educational reforms, safety, gender equality, decent salaries, as well as the right to speak out against corruption and urban violence, among other things. Clearly, such demonstrations would not be possible in totalitarian regimes, where the degree of freedom of speech and action is nonexistent. In such regimes, it is prohibited to use the streets and squares as places of resistance against sequestered freedom. In totalitarianism, there are physical spaces that characterize the streets, squares, precincts and parks, but there is no space of freedom or for reaction by those who are dominated.

The demonstrations to which we are referring were organized through virtual social networks, and used the streets, squares and avenues of our cities as their stage. In the city of Sáo Paulo, as well as other cities across the country, one of the main characteristics of these demonstrations was the itinerant character, with displacements from one point, where they gathered, to another (or others) in the city.

In the series of demonstrations organized by the Free Transport Pass Movement (MPL) during 2013 and 2014, in São Paulo, most of them occurred in the centralsouthwest region of the new old-city center: gathering on Avenida Paulista, moving off towards the center, or gathering at Largo da Batata in the neighborhood known as Pinheiros, moving off towards Paulista and the center, or gathering in the Ramos de Azevedo Square, in front of the Municipal Theatre, and moving off towards Avenida Paulista ${ }^{1}$. The demonstrations took place against the planned increase in public transport fares, and which according to an article by the organizers for Rebel Cities (MOVIMENTO PASSE LIVRE, 2013, p. 1, author's translation), were needed so as to ensure "workers' access to the wealth of urban space", access which is invariably conditioned by the use of public transport. According to them, by taking over the streets during the demonstrations people had removed the administration of fare policy away from the city and onto themselves, which resulted in the government reversing the intended increase for public transport: buses, subways and trains.

Such demonstrations erupted violently because of the disproportionate response of the police in their crack down on protesters, especially on those involved in the depredation of banks, imported car showrooms, cafeterias and public institutions, as an expression of discontent against capitalism. However, these aspects of the demonstrations were broadly classified and disseminated by the media as acts that went against the interest of the common good, lacking urbanity,

But why did these protests take place within this area and not in other regions of the city? Or why did they not occur in areas where the vast majority of public transport users are concentrated? Harvey (2014, p. 212, author's translation) states that the characteristics of each place chosen to stage the popular demonstrations "are important, and the physical and social reengineering and territorial organization of these places are weapons in political struggles," leading us to indicate the relevance of these characteristics for the outbreak of the abovementioned movement.

In fact, it was into the southwest sector of the city of São Paulo where historically, the vast majority of its ruling class segregated itself, as demonstrated by Flávio Villaça
1 Of the demonstrations during the cited period, some took place on the outskirts of the city of São Paulo, such as the pamphlet distribution campaign in Jardim Angela, in May 2013, the demonstration on the Estrada do M'Boi Mirim in June 2013 and the blockade on the Dutra highway in June 2013. 
(1998) in Espaço Intra-Urbano no Brasil (Intra-urban space in Brazil). It is the part of the city that due to the concentration of political and economic power of its occupants, has received more attention and investments from local government, much to the detriment to other areas of the city: it is better structured in terms of its business and services networks, in its urban infrastructure network (the area with the greatest number of subway lines, long stretches of tunnels, overpass complexes, bridges and express avenues), in its facilities for health, education and culture, and in the qualification and maintenance of its public spaces, where the major public and private institutions are concentrated.

It is also in the southwest sector of the city where Avenida Paulista, Avenida Faria Lima and Avenida Berrini are located, central points created by the ruling classes ever since the late 1960s when they lost interest in the center of São Paulo - the so-called Central Sé Cathedral Republic. Until the 1960s, the center of São Paulo was the exclusive domain of this social minority. The abandonment of this region to which we refer was only not complete, because in order to maintain its condition as the ruling class the bourgeoisie, once again returning to Villaça (1993), has systematically pressed the state to promote interventions within that region. After all, the center of the city still retains a great affective, cultural and symbolic value for the majority of the population.

During the 1990s, Avenida Paulista was elevated to become the new status symbol of the city of São Paulo, through a campaign run by Banco Itaú, for which those voting were not offered any other options and more recently, the Estaiada Octavio Frias de Oliveira Bridge, built on the Marginal Pinheiros, close to Roberto Marinho Avenue, so that only motor vehicles - predominantly private - could cross the River Pinheiros, became the new symbol of the city, by being transformed into a backcloth for a daily Globo TV news program. Indeed, the southwest sector of the city of São Paulo is the sector of the ruling class, where the creation and manipulation of its symbols contribute ideologically to legitimize its process of domination.

The outbreak of popular protest demonstrations in the streets, squares and avenues of the southwestern sector and center of São Paulo, a key region in the process of domination, and therefore segregated by higher income levels, where fundamental class relations are concealed (HARVEY 2006; VILLAÇA, 1998), highlights the political expression taken on by the public spaces where such events occur, whether these spaces are squares, streets or avenues.

In this respect, it would seem that the design, dimensions and topography of these spaces do not seem to have been decisive factors in choosing Avenida Paulista, Avenida Faria Lima, Largo da Batata, Avenida da Consolação, Praça Ramos, or Viaduto do Chá, where the outbreaks of these demonstrations took place. These spaces are symbolically relevant for the whole population, but contain no similarities of design, dimension or topography. This therefore, leads us to raise questions concerning the correspondence between urban form and the possibility of political achievement. In this aspect, Delgado states (2011, p. 73, author's translation):

[...] there is a kind of urban idealism from which we work with the idea that urban form is a kind of system conducting human performances from conditioned reflexes generated by the placing of architectural volumes or by the arrangement of elements in public spaces. 


\section{FORM AND CONTENT}

The correspondence between the form of public spaces and human activities is very present in the discourses that accompany urban projects developed since the 1980s, especially in Europe and the US. One of the most paradigmatic of these urban projects, especially in relation to the significance and role associated with public spaces, was in Barcelona. Thus, El Espacio Público: ciudad y cidadania by Jordi Borja and Zaida Muxi (2003), the former being one of the main contributors to the Barcelona Plan, identified three dimensions that a public space should contemplate:

- $\quad$ urbanistic, capable of organizing a territory, supporting a diversity of uses and functions and creating places;

- cultural, because it should be: monumental, in order to express and fulfill a diversity of functions, an urbanistic reference, a symbol of collective identity, an expression of history and the power of will;

- political, because apart from being a space for the collective expression of community living, of the visibility of different social groups, of quotidian encounters, it should also be a space of affirmation and confrontation, a space for the large civil or social demonstrations.

Jordi Borja and Zaida Muxi (2003) based them arguments on this systematization in order to explain and attribute content to the public spaces that were being created in Barcelona, using the urban projects carried out for the 1992 Olympic Games. Without denying that the form and arrangement of the elements in public spaces may serve as stimuli for certain behavioral guidelines, the formation of public space created by Jordi Borja and Zaida Muxi (2003) does not seem, however, to consider that it is the entire population that appropriates and attributes meanings to public space.

This question seems to have been central for the administrators of the Faria Lima Urban Operation Consortium (an urban design modality deployed in the city of São Paulo, successful from the viewpoint of real estate interests) not to focus special attention onto the existing public spaces, nor onto those that were to appear. In the predominant space belonging to the ruling class, the landscape was composed of railings, walls, elevated gardens and corner squares. Here the public space serves only to exert its maximum degree of functionality: the circulation of predominantly public and private motor vehicles.

Achieving political expression in urban public spaces, as conceived by the Catalans in the Barcelona Plan, seems not to have been echoed in the main critical assessments of the large urban projects that emerged during this period, especially since, in the opinion of the critics these were projects that intensified territorial social exclusion, disregarding the possibility of social transformation, were elitist and authoritarian in the manner they were conceived and formulated, and in this sense, the use of these spaces becomes socially standardized (VAINER, 2013; DELGADO, 2011). Therefore, it was highly imporbable that these spaces would become a collective expression of community life, of the different social groups, of everyday encounters or of affirmation or of confrontation, as Jordi Borja and Zaida Muxi (2003) would like.

If the urban, cultural and political dimensions that a public space may eventually contain, are widely used in official discourses, whether technical or political, to justify and give meaning to the public spaces that appear, especially with the large urban projects from the 1980s, these dimensions, in particular the political, have also served, 
since this same period, as the starting point for analysing the conflicts encountered in the public spaces of our cities.

Indeed, during the 1980s, numerous publications succeeded in analyzing urban public spaces from a socio-political perspective. They registered the spaces of our streets, squares, parks and avenues as spaces belonging to the public sphere, public opinion, public life, in an explicit reference to the concepts, located in the field of political philosophy, of two of its greatest creators: Hannah Arendt, in The Human condition, in 1958, and Jürgen Haberrmas in The Structural Transformation of the Public Sphere (Strukturwandel der Öffentlichkei), in 1962. Additionally, in the mid-1970s, Richard Sennett also became a frequent reference in the literature regarding urban public spaces, mainly through the sociological studies contained in his book The Fall of Public Man, published in 1974.

From this universe of thinkers, Hannah Arendt (1993), gave rise to the contemporary reconstruction of the political thought of Aristotle, by identifying the public sphere as a meeting of individuals who monitor the exercise of power and make pronouncements on subjects related to life as in the Greek Agora (or the Roman Forum). In this case, she linked the public sphere of praxis and discourse as a manifestation of public life in the physical space of the polis.

Otilia Arantes (1995, p. 117, author's translation) indicates that it was in the Greek polis that Arendt sought the model from which she judged the modern transformation of the public sphere, i.e., the dissolving of the harmonious distribution between public and private, caused by the indefinite expansion of private territory, concurrently with the decline of the public nature of freedom and therefore the public visibility of mass society. In his view, Arendt took as a "[...] paradigm an interpretation of ancient politics as the domain of joint action, action triggered by the discursive practice exercised between equals."

In his reflections, Habermas (1984) established the process that, from the eighteenth century, led to the construction of bourgeois political domination, and which led to the institutionalization of the moral structure of the activity of governing on the basis of a socio-political structure founded on formal - or public - freedoms, and on equality before the law. Hence, Habermas (1984) systematized the formation of the bourgeois state.

Interestingly, in Lavalle (2001, p. 38), we observe that the historical features in Habermas expressed a constellation of strongly interwoven factors (market expansion, the emergence of the nuclear family, urbanization, proliferation of the social habit of reading, the peak of the press, etc.), which demonstrated a correspondence between the public sphere and two types of institutional crystallization: the affirmation of bourgeois autonomy in practices and spaces of dialogic interaction (reading clubs, saloons, coffee and tea houses, conversational gatherings, Masonic lodges and various societies of a cultural nature) and a set of institutions dedicated to publicly conveying the opinions that represented the interests of this social segment of free proprietors (newspapers, leagues, clubs and extra parliamentary political associations).

In Brazil, the reflections of Marilena Chauí (1998) present public space as a social space of struggles (social movements, popular movements) and as the political forms of permanent expression (political parties, rule of law, economic and social policies). The sense of public space in Chauí (1998) subscribes to the circle of concerns by leftist intellectuals from the central countries, which according to Rosalyn Deutsche 
(1998, p. 272) during the 1970s and 1980s were involved in renewing theories on democracy. ${ }^{2}$

With the exception of the Greek model - gatherings of individuals who inspected the exercise of power and made pronouncements on subjects related to life like in the Greek Agora (or the Roman Forum) - that Hannah Arendt (1993) sought to reconstruct in contemporaneity, none of the other conceptions from the fields of philosophy and politics associated the notions of the public sphere/public space to a physical complement, whether it was the street, the square, the park, largo the avenue, or the boulevard, among others. All of them, abstract concepts that in their formulation did not take into account the materiality of urban spaces.

\section{THE STREET IN COMBATTING AUTHORITARIANISM}

The transposition of the concepts formulated in the fields of politics and philosophy for urban public spaces, widely used since the 1980s, has been paved by city planners, with a humanist profile, who, from the 1960s/1970s, began to identify the streets and squares of our cities as the main antidote for the functionalist urbanism introduced by modern architects and urban planners, who favored functionality, accessibility, circulation and speed in our cities.

A reference book for specialists in public spaces, The Death and Life of Great American Cities, written by Jane Jacobs and published in 1961, locates within the interventions established within the principles of modern planning, as proposed by Moses for the city of New York, an end to the diversity of uses in the streets, which she considers fundamental for the economic and social vitality of our cities. In fact, the impact of the interventions proposed by Robert Moses for the city of New York, which were respectively, the creation of extensive roadways, the parkways, which enabled the emergence of low density residential suburbs in the 1930s and 1940s and, in the 1950s and 1960s the construction of expressways, especially the overpasses that, unlike the parkways, were fully inserted into the urban area of New York, caused the emergence of acid criticism towards this kind of urbanism.

Separating the functions of the traditional cities: commerce from the residential and green areas; changing the basic unit of urban design - the street - to the blocks and superblocks and the need for a new order, to the detriment of the disorder within ancient cities, are some of the principles of modern planning that Jacobs (2003) identified and sought to deconstruct in her work.

In Europe, the valorization of streets, squares and avenues of the traditional cities, as the main antidotes for modern planning was the object of researchers and scholars of urban issues, such as Aldo Rossi and Henri Lefebvre and Richard Sennett. In The Fall of Public Man, Sennett (1988) examined the formation of public space for the manifestation of public life, which in his view, had become stigmatized since the 1960s by the public space derived from the movement. He cites two examples - Lever House and La Defense, respectively, the so-called international style and icons of urban roadways - in order to demonstrate that public space is reduced to a single function, to mobility linked to transport; the street becomes a place of obligatory passageway between transport and support to households or offices, thus losing all their social significance.
2 The thinkers to whom Rosalyn Deutsche (1998, p. 272) was referring, were: Claude Lefort, Ernesto Laclau, Chantal Mouffe, Etiene Balibar, Jean Luc Nancy and Philippe Lacoue-Labarthe. For her, Lefort was one of the pioneers in the debates that structured the ideas that emerged as the key points in the discussions on radical democracy. 
Also in Brazil, since the 1960s, the threat to the street as the main structuring element of economic and social diversity of the city has generated strong criticism regarding the functionalist principles that influenced Brazilian urban planning. Here we would highlight the work of the architect Carlos Nelson Ferreira dos Santos (1981; 1984; SANTOS; VOGEL, 1981).

During his short career of a little over 20 years, developed during the time of the military dictatorship in Brazil, Carlos Nelson Ferreira dos Santos, who graduated in 1966 from the Faculdade Nacional de Arquitetura in Rio de Janeiro, confronted and attempted to overcome the difficulties at that time of establishing public space as a social space for struggles, social movements, and popular movements.

Involved in participatory urban redevelopment processes in the favelas of Brás de Pina and Morro Azul in Rio de Janeiro, Carlos Nelson and a group of friends encountered the refusal by Pina Brás residents to deploy some of his proposals, most notably: the implementation of a socializing urbanization in the form of a horizontal condominium without the division of lots; a choice of places to deploy common open spaces and services, and even the construction of an open building with indefinite spaces between the public and private, to be built in the Central Square as a manner of signaling to the entire population that this was their house, the center of their interests, the representation of their unity - the Agora of Brás de Pina.

A decade later, in 1979, on returning to Bras de Pina for his dissertation, Carlos Nelson would argue that the issues revealed in the urbanization of the abovementioned favela, especially regarding the disinterest of its residents in designing a permanent physical space for participation and for demanding their rights - the political in the physical space -, were not reflections of a crisis with a urban character, but a consequence of the manner in which cities, under authoritarian rule, were appropriated by the Brazilian capitalist development model and transformed by progressive-rationalist urbanist assumptions.

Another work by Carlos Nelson worthy of mention for the purposes of this study, was jointly developed with Arno Vogel, which resulted in the book Quando a rua vira casa (When the street becomes home). This was an ethnographic research concerning the traditional district of Catumbi, a modern housing complex, known as Selva de Pedra (Concrete Jungle) and an exclusive condominium that appeared in Barra da Tijuca known as Riviera dei Fiori (one), all located in Rio de Janeiro.

This research aimed to evaluate the profound transformations, both the physical and within the relationships of society with its city, brought about by major structural road projects - expressways; tunnels; overpasses and flyovers - all mainly geared towards private vehicles, and by the large housing complexes and private walled condominiums, among others, through joining together the established spaces and the great degree of varied activities that existed within them.

They observed that in Catumbi, the borders were fluid, i.e., there was nothing appropriate for each space and no appropriate space for each thing, there was a mixture corresponding to an urban lifestyle of the area, and therefore depended on the context.

Using these observations, Carlos Nelson and Arno Vogel (1981) argued that the street was the fundamental means of developing citizenship and civility. They understood citizenship as a conviction of belongingness within a social universe that shares a set of representations and social relations as something more than just a formal 
status, but rather an exercise of responsibility regarding what is common and civility, as the appropriate exercise of applying the rules and therefore their daily reproduction at the level of sociability.

They also found that the ongoing practice of negotiation as a form of undoing any undesired clashes or of forming hierarchies and making the different forms of appropriation provided for diversity compatible, was the basis of active public and social life. This they called, in reference to Hannah Arendt, the "rhetoric of persuasion."

In their observations on the Selva de Pedra housing complex, they indicated that there was a clear concern regarding the separation of functions and spaces, where each function must only correspond to the use for which it was appropriate, with the objective of establishing univocal, homogeneous and transparent spaces, or stated in another form, avoiding ambiguities.

The lack of diversity and the option of an architecture that favored transparency, aligned to an increase in violence, mistrust and insecurity, as well as the ruthless appropriation of spaces on the streets and sidewalks for vehicles to circulate and park, demonstrated a paradigm of urban life to Carlos Nelson and Arno Vogel (1981), which emphasized the individual, his/her privacy and autonomy in relation to the other, although in the latter case the functions of safety, mediation and control were particularized institutionally.

In the case of the Riviera dei Fiori, where common spaces were totally privatized, Carlos Nelson and Arno Vogel (1981) argued that in this enterprise the rules and practices reified in the regulations prevailed, without mediation from the communities in the streets. In this case, the central argument of the architects was that this type of consortium of private capital constituted a model of urban development that was based on changes in code values, brought about by the loss of citizenship and the lack of interest in urban issues - officially encouraged by bureaucracy and authoritarianism - exactly at a time when Brazilian politics began to show clear signs of moving towards democratic openness.

Within his various considerations concerning the exclusive condominiums, Carlos Nelson demonstrated his concern over the privatization of urban public spaces and the consequent decrease of the public pivot. In this regard, he drew attention to the relevance and urgency of installing political public spaces as a way for the poorest part of the population to make decisions on urban issues or, put another way, as a form of distributing political power across the cities.

Indeed, with the political opening in Brazil and, consequently, the end of authoritarianism, Carlos Nelson was proposing the creation of a political public space (participation and communication) as a means of democratizing decisions on the fate of cities, and founding an ideal model of social relations, which encountered its ideal expression on the streets of traditional cities. In this perspective, as Carlos Nelson demonstrated with his research in Catumbi, the street acquires the fundamental means of developing citizenship and civility, the place for the permanent practice of negotiation, in short, the locus of active social and public life. 


\section{THE OVERLAP OF POLITICAL ACHIEVEMENT IN URBAN PUBLIC SPACES: APPROACHES}

Reflections on the work of Richard Sennett (1988) and Jane Jacobs (2003); in Lefebvre's (1997) critique of attempting to reproduce the complex social structure of a historic city in the large post-war housing complexes and the arguments by Carlos Nelson Ferreira dos Santos $(1981 ; 1984)$ on the political nature of the urban public place, among others, have paved the way for several approaches in relation to the meaning of urban public spaces in democratic societies.

Undeniably, if the streets, squares and avenues of the historically built cities were taken as an antidote to urban and social ills attributed to rationalistic and authoritarian planning, with capitalism turning towards neoliberalism and the worsening of social dilemmas associated with the reproduction of certain urbanistic models (shopping centers, exclusive condominiums, Disney World, etc.), they began to replicate analyzes supported by the political character of those spaces.

To illustrate the diffusion of such analyzes, we will cite a number of authors, whose publications have become references in research and studies on public spaces. To this end, we have grouped them around the central issues that were common to them all, specifically: the correspondence between the manifestation of contemporary public life and traditional public places (Michael Brill and Stephen Carr et al.); the relationship between democracy, the privatization processes of public space and the recovery of the public pivot (Sharon Zukin, Gilles Lipovetsky, Rosalyn Deutsche, Diane Ghirardo, Antonio Arantes, Eduardo Yázigi, Paulo Cesar da Costa Gomes, Heitor Frúgoli Jr, Ali Madanipour, New Urbanism) and the character and the degree to which spaces are public (Lês Annales de la Recherche Urbaine, Herman Hertzberger).

The reflections by Michael Brill (1989) and Stephen Carr et al. (1992) derive from discussions on the possible reduction in the public life of American society in the traditional public places (streets, squares and parks). Contrary to Carr's arguments, for whom the reduction of the public space implied the disappearance of American public life, Brill (1989) argued that this reduction did not imply the impoverishment and decay of public life, but rather a transfer of this manifestation to other places identified generically as communication channels: such as the internet, local newspapers, local TV programs, among others.

The findings of Carr et al. (1992) and Brill (1989) become relativized in the face of the manifestations to which we refer herein, since the importance of contemporary communication media became evident, such as the internet and social networks, in coordinating and disseminating protests in public spaces; thus strengthening the expression of public life in those spaces.

In the discussions surrounding the traditional forms of cities as a means of restoring its public pivot, Lipovetsky argues (1991) that only the restitution of public space in cities can counter the postmodern individualist logic responsible for causing changes in the political public space, due to the de-ideologization developed through the disinterest in large systems of representation and opinion.

In his view, this represents the end of the great social utopias (nobody believes in promises to change the world, no one wants revolution, no one talks of destroying capitalism and the market economy) and of mass demobilization (the confrontation 
between the right and the left has lost its earlier radicalism) and the desecration of trade unions (collective movements had become increasingly independent of political parties and trade unions).

For Lipovetsky (1991), urbanism in the twentieth century, by causing an explosion of interpenetration between public and private through the condemnation of a mixture of housing, offices, public squares, as well as the coexistence of homes and factories in the same street, have contributed to the death of cities dominated by the public pivot, and the recurrent social atomization.

Interestingly, the manifestations and the frequency with which they have occurred in several countries on the four continents, seem to have weakened Lipovetsky's (1991) argument regarding the end of social utopias and the demobilization of the masses due to the reduction of the public pivot in cities.

Perhaps the most intriguing analytical approaches that have emerged since the 1980s for public spaces have been those that have dealt with the appropriation of public space, not only in a standardized and legitimized manner by the government, but also spontaneously without necessarily being standardized or legitimized by the government. In the first case we highlight the work of sociologist Sharon Zukin (1996) who analyzed the way in which many public spaces are managed by commercial and corporate forces in US cities, especially in New York. For her, this form of ownership has caused negative effects on urban public culture.

Her argument is that urban public culture, derived from social encounters that shape the daily life of streets and parks, stores and other spaces in which we experience public life in the cities, is being conditioned by the investments applied to urban public spaces, as well as the right and the condition of being able to use and of using such spaces, in other words, her assumption is that the democratic essence and construction of public culture in urban public spaces of North American cities are being shaped by people with economic and political power and interests. In her view, such logic favors the strengthening of what she has called the symbolic economy of the city, in "[...] its visible ability to produce visible symbols and spaces: the symbiosis of image and product, the scope and scale of selling images on a national and global level and the role of the symbolic economy in speaking for or representing the city" (Zukin, 1996, p. 133). In short, the strength of marketing to produce and intervene in urban public spaces.

Social control legitimized by the US Government to delegate investment in the management and maintenance of public spaces to commercial and corporate forces in return for conceding areas of public spaces for commercial exploitation, is indicated from another angle by Diane Ghirardo (2002), in a critical analysis on the megaprojects - theme parks, shopping-malls, etc. - that have spread across the US, since the 1950s. For her, these are models that subtract public life in American cities because they exercise control, by seeking to redefine public spaces as being private. Ghirardo's (2002) central argument is that these mega-projects, by attracting stores and buyers away from the heart of the cities, have led to the general decline of many traditional retailing neighborhoods in major cities across the US, Canada and the UK, and have kept out any type of spontaneous political and social activities associated with cities, thus sanctioning the sense of these mega-projects as carefully controlled places, and thereby reducing the notion of civic participation to mere consumption.

From the perspective of appropriating of a square in New York for the homeless, which occurred spontaneously without legitimacy or regulation by the government, 
Sergio Luis Abrahão graduated in Architecture and Urbanism at the Universidade Presbiteriana Mackenzie (UPM); he has a master and doctorate degree in Architecture and Urbanism from the Faculty of Architecture and Urbanism at the Universidade de São Paulo (FAU/USP); he is a professor at FIAM-FAAM Centro Universitário.

E-mail: sabrahao@bighost. com.br

Article received on 13 th Septemeber 2015 and approved for publication on 7th Decemebr 2015.
Rosalyn Deutsche (1998) focused on analyzing the official discourses, which were supported by democratic attributes so as to justify decisions on the use and appropriation of public spaces in US cities, especially in New York. Rosalyn Deutsche (1998) noted that those who spoke more in the name of absolute social meanings (freedom, equality) - in her view a democracy in an authoritarian direction - were mobilized to induce approval in new forms of subordination, taking uncontested gentrification processes into urban public spaces, unlike those who spoke on behalf of circumstantial meanings (political).

For her, the threat appears exactly with the efforts to annul the conflict, because the public sphere remains democratic only to the extent that their exclusions are taken into account and open to contestation. In her view, conflict, division and instability do not ruin the democratic public sphere; but are, above all, the conditions for its existence. She argues that to claim that the public space is the place of democratic political activity may be reflected in a reduction of policies that one allegation such as this seeks to challenge. The policy, she states, cannot be reduced to something that happens within the confines of urban public space and the political community. As an way out, Rosalyn Deutsche (1998) suggests that the specific socioeconomic conflicts that produce social ills - such as the homeless and gentrified urban public spaces, were not simply accepted as evidence of the inevitability of conflict, but rather, they were politicized, open to the challenge as a social issue.

Indeed, the political dimension of public spaces is evident when exclusionary processes of access to urban spaces are politicized within them, either by private appropriation of the spaces, or by the privatization of essential public services for this access, an example of which is public transport, or yet still, when the idea of urbanity is put into question, as a system of good civic practices, repeatedly conveyed through planning and policy management submitted for the interests of the ruling minority. In this direction, rather than the form, dimensions and topography, the symbolic aspect of public spaces proves to be of fundamental importance.

\section{REFERENCES}

ARANTES, O. O lugar da arquitetura depois dos modernos. 2. ed. São Paulo: Ed. USP, 1995. ARENDT, H. A Condição Humana. 6. ed. Rio de Janeiro: Forense Universitária, 1993. BORJA, J.; MUXÍ, Z. El Espacio Público: ciudad y ciudadanía. Barcelona: Electa, 2003.

BRILL, M. Transformation, nostalgia and illusion in public life and public space. In: ALTMAN, I.; ZUBE, E. H. (Ed.). Public Places and Spaces. New York: Plenum, 1989. v. 10. p. 7-29.

CARR, S. et al. Public Space. Cambridge, USA: Cambridge University Press, 1992.

CHAUÍ, M. O espaço público e a democracia (mimeo). Seminário Internacional O Espaço Público e Exclusão Social, São Paulo, 1998.

DELGADO, M. El Espacio Público como Ideología. Madrid: Catarata, 2011.

DEUTSCH, R. Evictions: Arts and Spatial Politics. Londres: MIT, 1998.

FRANCK, K. A.; PAXSON, L. Women and Urban Public Space. In: ALTMAN, I.; ZUBE, E. H. (Ed.). Public Places and Spaces. New York: Plenum, 1989. v. 10. p. 121-143.

FRUGOLI JUNIOR, H. Espaços Públicos e Interação Social. São Paulo: Marco Zero, 1995.

GHIRARDO, D. Arquitetura Contemporânea: Uma história concisa. São Paulo: Martins Fontes, 2002. 
GOMES, P. C. C. A Condição Urbana. Rio de Janeiro: Betrand Brasil, 2002.

HABERMAS, J. Mudança Estrutural da Esfera Pública. Rio de Janeiro: Tempo Brasileiro, 1984.

HARVEY, D. The Political Economy of Public Space. In: LOW, S.; SMITH, N. (Ed.). The Politics of Public Space. New York: Ed. Taylor \& Francis Group, 2006. p. 17-35. Cidades Rebeldes. São Paulo: Martins Fontes, 2014.

JACOBS, J. Vida e morte das grandes cidades americanas. São Paulo: Martins Fontes, 2003.

LAVALLE, A. G. Espaço e vida públicos: reflexóes teóricas e sobre o pensamento brasileiro. 2001. Thesis (Doctorate in Political Science) - Faculdade de Filosofia, Letras e Ciências Humanas, Universidade de São Paulo, São Paulo, 2001.

LEFEBVRE, H. Propositions. Urbanisme, Architecture D'Aujourd'hui, n. 132, p. 14-16, 1967.

LERNER, J. O Desenvolvimento Urbano no Brasil. Revista Brasileira do Planejamento, Porto Alegre, p. 10-23, jun. 1978.

LIPOVETSKY, G. Espace privé, espace public à l'âge postmoderne. In: BAUDRILLARD, J. et al. Citoyenneté et urbanité. Paris: Esprit, 1991. p. 105-122.

MOVIMENTO PASSE LIVRE. Não Começou em Salvador, não vai terminar em São Paulo. In: MARICATO et al. Cidades Rebeldes: passe livre e as manifestações que tomaram as ruas do Brasil. São Paulo: BoiTempo: Carta Maior, 2013. p. 13-18.

SANTOS, C. N. F. Movimentos Urbanos no Rio de Janeiro. Rio de Janeiro: Zahar, 1981.

- Formaçóes metropolitanas no Brasil: mecanismos estruturantes. 1984. Thesis (Doctorate in Architecture and Urbanism) - Faculdade de Arquitetura e Urbanismo, Universidade de São Paulo, São Paulo, 1984.

; VOGEL, A. Quando a rua vira casa. 2. ed. Rio de Janeiro: Finep, 1981.

SENNET, R. O Declínio do Homem Público. São Paulo: Companhia das Letras, 1988.

VAINER, C. Grandes Projetos Urbanos: significados e formas de avaliação. In: CUENYA, B.; NOVAIS, P.; VAINER, C. (Org.). Grandes Projetos Urbanos: olhares críticos sobre a experiência argentina e brasileira. Buenos Aires: Masquatro Editora Ltda; Editorial Café de las Ciudades Ltda, 2013. p. 135- 166.

VILLAÇA, F. A produção e o uso da imagem do centro da cidade: o caso de São Paulo. São Paulo: 1993 (mimeo). . Espaço Intra-Urbano no Brasil. São Paulo: Studio Nobel: FAPESP, 1998.

YÁZIGI, E. O mundo das calçadas: por uma política de espaços públicos em São Paulo. 1997. Thesis (Livre-Docência apresentada ao Departamento de Geografia) - Faculdade de Filosofia, Letras e Ciências Humanas, Universidade de São Paulo, São Paulo, 1997.

ZUKIN, S. Whose Culture? Whose City? In: LEGATES, R.; STOUT, F. (Org.). The City Reader. 2. ed. Londres: Nova Iorque: Routledge, 1996. p. 131-142. 